\title{
Measurement of pH, alkalinity and acidity in ultra-soft waters
}

\author{
Lahav $\mathrm{O}^{1 *}$, Morgan $\mathrm{BE}^{2}$ and Loewenthal $\mathrm{RE}^{2}$ \\ ${ }^{1}$ Faculty of Agricultural Engineering, Technion - Israel Institute of Technology, Haifa 32000, Israel \\ ${ }^{2}$ Department of Civil Engineering, University of Cape Town, Rondebosch 7700, South Africa
}

\begin{abstract}
Conventional characterisation of low alkalinity waters via $\mathrm{pH}$ measurement and titration of total alkalinity to a prescribed end-point invariably leads to large errors. These errors result from instability of the $\mathrm{pH}$ probe and an unknown titration end-point. In this paper two indirect methods (termed the "double Gran function" and the "blend" method) for the characterisation of such waters are evaluated critically. A blend composed of the raw water, sodium chloride (to increase conductivity), and standard bicarbonate (to increase buffering capacity) was titrated with standard strong acid in two $\mathrm{pH}$ regions: $6.3<\mathrm{pH}<7.0$, and $3.5>\mathrm{pH}<4.0$. In both methods, total alkalinity was determined using the latter set of points, and the first Gran function. In the double Gran function method the upper set of titration points was used to determine $\mathrm{CO}_{2}$ acidity using the second Gran Function. In the "blend" method, equilibrium chemistry data were used to calculate total acidity for each point based on the known total alkalinity, $\mathrm{pH}$ reading, temperature and ionic strength. The two methods gave excellent results (in terms of both repetition and accuracy) as compared to characterisation based on total alkalinity and inorganic carbon analysis. A detailed procedure for the execution of the two approaches is given in an appendix.
\end{abstract}

\section{Introduction}

Natural terrestrial waters on the eastern seaboard region of all the continents in the southern hemisphere have low alkalinity and hardness and are usually slightly acidic; incidents of such waters arise also in most of the northern hemisphere continents.

In South Africa such waters occur from just south of Durban to Cape Town. These waters are corrosive to metals and aggressive to cement materials. Consequently, stabilisation is required prior to distribution. Usually stabilisation is effected via lime (to increase calcium and alkalinity concentrations) and $\mathrm{CO}_{2}$ addition to obtain a slight supersaturation with respect to $\mathrm{CaCO}_{3}$ (Loewenthal and Marais, 1976). Dosages to be applied depend on the initial characteristics of the water, i.e. $\mathrm{pH}$, total alkalinity (referred to here as Alkalinity, referring specifically to the alkalinity associated with $\mathrm{a}_{2} \mathrm{CO}_{3}{ }^{*}$ reference solution) and $\mathrm{Ca}^{2+}$ concentration. In this regard Alkalinity and $\mathrm{pH}$ measurements for these waters pose problems. The difficulty with measuring Alkalinity arises from its low value (usually less than $10 \mathrm{mg} / \ell$ as $\mathrm{CaCO}_{3}$ and sometimes as low as $1 \mathrm{mg} / \ell$ ) and an unknown titration end-point. For $\mathrm{pH}$ the problem is one of instability of the probe in the low buffer/low ionic strength waters. These problems are highlighted in Table 1 below in which are listed results from five analytical laboratories on the eastern seaboard for Alkalinity and $\mathrm{pH}$ analyses of a particular water. The magnitude of the differences between the "true" values and the variable results measured by the laboratories is best presented by comparing the total acidity (referred to here as Acidity, referring specifically to the Acidity associated with an $\mathrm{CO}_{3}^{2-}$ reference solution) values of the water calculated from the measured data with their "real" Acidity value calculated from an Alkalinity (measured via Gran function) and total dissolved inorganic carbon (measured using inorganic carbon analyser). The large errors likely to arise in characterisation from "conventional" Alkalinity and pHobservations lead to extreme

\footnotetext{
* To whom all correspondence should be addressed.

而972-4-8293479; fax: 972-4-8221529;

e-mail: agori@techunix.technion.ac.il

Received 3 May 2001; accepted in revised form 15 August 2001.
}

problems in design and control of water treatment plants in soft water regions.

The problems that arise in these measurements can be summarised briefly as set out below:

\section{Alkalinity measurement problem}

Currently most laboratories measure Alkalinity by titration to a fixed end-point (i.e. to a colorimetric or $\mathrm{pH}$ end-point) [The term Alkalinity is used here to define the proton-accepting capacity with respect to carbonic acid as reference point]. For low Alkalinity waters, this is unsatisfactory because of the difference between the true titration end-point and that used (or reflected by the indicator used). For these waters Standard Methods (1998) propose an approximate method based on titration to an arbitrary end-point (anywhere between 4.3 and 4.7). However, this results in large relative errors.

Less often used is a Gran titration (Gran, 1952). The method is accurate, easily effected and independent of a titration end-point.

\section{pH measurement problems}

The problem of $\mathrm{pH}$ instability in low Alkalinity waters can be partially resolved using glass and reference $\mathrm{pH}$ electrodes specifically designed for these waters. However, these are expensive and fragile and most laboratories are not equipped with them. It should be noted, however, that even with these electrodes measurements are still not necessarily reliable as discussed below.

Characterisation of the carbonate system (i.e. the weak acid system controlling $\mathrm{pH}$ ) in terrestrial waters requires measuring any two independent parameters for this system in water (in addition to temperature and ionic strength). The independent parameters available include Alkalinity, Acidity, $\mathrm{CO}_{2}$ acidity, total dissolved inorganic carbon $\left(\mathrm{C}_{\mathrm{T}}\right)$ and $\mathrm{pH}$ [The terms Acidity and $\mathrm{CO}_{2}$ acidity are used here to define the proton-donating capacity with respect to $\mathrm{CO}_{3}^{2-}$ and $\mathrm{HCO}_{3}$ as reference species respectively]. Recognizing that Alkalinity can be measured accurately using a Gran titration, 
and that (i) Acidity cannot be measured directly (Loewenthal and Marais, 1976), (ii) measurement of $\mathrm{C}_{\mathrm{T}}$ requires an expensive inorganic carbon analyser, and (iii) $\mathrm{pH}$ measurement is impractical for reasons described above, measurement of the remaining parameter, i.e. $\mathrm{CO}_{2}$ acidity also should be considered. Standard Methods (1998) proposes titration to $\mathrm{pH} 8.3$ using a standardised base, but does not propose a method for $\mathrm{CO}_{2}$ acidity measurement in very poorly buffered waters where the problem of $\mathrm{pH}$ measurement arises. Such consideration is effected in this paper and shown to be acceptable, provided that sodium chloride and standard bicarbonate are added to the test solution.

In this paper, an in-depth investigation is effected into the various means of characterising low-alkalinity waters. The methods investigated include:

- Direct characterisation via measurement of Alkalinity (using Gran function) and $\mathrm{pH}$ using various probes available on the market.

- Indirect characterisation where a blend of sample, standard bicarbonate solution and sodium chloride is used. Characterisation of the blend is then effected via:

- Measurement of Alkalinity using the first Gran function and $\mathrm{CO}_{2}$ acidity using the second Gran function. From these analyses, the characteristics of the raw water are determined.

- Measurement of Alkalinity (as above) and measurement of $\mathrm{pH}$ of the blend after addition of standard acid to adjust to a well-buffered zone $(6.3<\mathrm{pH}<7.0)$. From these analyses, the characteristics of the raw water are determined.

Before dealing with these methods, it is necessary to review briefly the capacity parameters for the carbonate system (i.e. various forms of alkalinity and acidity) and their interactions with $\mathrm{pH}$ via equilibrium equations.

\section{Theory}

\section{System parameters}

$\mathrm{pH}$ in natural terrestrial waters is governed principally by the carbonate system. Equilibrium relationships for this system in water are:

$$
\begin{aligned}
& \left(\mathrm{H}^{+}\right)\left[\mathrm{HCO}_{3}^{-}\right] /\left[\mathrm{H}_{2} \mathrm{CO}_{3}^{*}\right]=\mathrm{K}_{1}^{\prime} \\
& \left(\mathrm{H}^{+}\right)\left[\mathrm{CO}_{3}^{2-}\right] /\left[\mathrm{HCO}_{3}^{-}\right]=\mathrm{K}_{2}^{\prime} \\
& \left(\mathrm{H}^{+}\right) /\left[\mathrm{OH}^{-}\right]=\mathrm{K}_{\mathrm{w}}^{\prime}
\end{aligned}
$$

where:

$$
\begin{array}{rll}
(\mathrm{x}) & = & \text { activity of species } \mathrm{x} ; \\
{[\mathrm{x}]} & = & \text { molarity of species } \mathrm{x} ; \\
\mathrm{K}_{1}^{\prime}, \mathrm{K}_{2}^{\prime}= & \text { thermodynamic equilibrium constants adjusted } \\
& \text { for Debye-Huckel affects; } \\
{\left[\mathrm{H}_{2} \mathrm{CO}_{3}^{*}\right]=} & {\left[\mathrm{H}_{2} \mathrm{CO}_{3}\right]+\left[\mathrm{CO}_{2(\mathrm{aq})}\right] .}
\end{array}
$$

The three equations above include five weak acid parameters - this observation forms the basis for the need to measure two independent parameters in order to characterise a water. In addition to the above equilibrium equations, a number of proton balance (alkalinity and acidity) equations and a mass balance equation for the dissolved carbonate species can be developed in terms of weak acid species concentrations, giving:

$$
\text { Alkalinity }=2\left[\mathrm{CO}_{3}^{2-}\right]+\left[\mathrm{HCO}_{3}^{-}\right]+\left[\mathrm{OH}^{-}\right]-\left[\mathrm{H}^{+}\right]
$$

$$
\begin{array}{r}
\mathrm{CO}_{2} \text { acidity }=2\left[\mathrm{H}_{2} \mathrm{CO}_{3}{ }^{*}\right]-2\left[\mathrm{CO}_{3}{ }^{2-}\right]+\left[\mathrm{H}^{+}\right]-\left[\mathrm{OH}^{-}\right] \\
=-\mathrm{CO}_{2} \text { alkalinity } \\
\begin{aligned}
\text { Acidity }=2\left[\mathrm{H}_{2} \mathrm{CO}_{3}{ }^{*}\right] & +\left[\mathrm{HCO}_{3}^{-}\right]+\left[\mathrm{H}^{+}\right]-\left[\mathrm{OH}^{-}\right] \\
\text {Total inorganic carbon } & =\mathrm{C}_{\mathrm{T}}=\left[\mathrm{H}_{2} \mathrm{CO}_{3}{ }^{*}\right]+\left[\mathrm{HCO}_{3}^{-}\right] \\
& +\left[\mathrm{CO}_{3}{ }^{2-}\right]
\end{aligned}
\end{array}
$$

These mass and capacity parameters are interdependent as follows:

$$
\begin{aligned}
& \text { Alkalinity }+ \text { Acidity }=2 \mathrm{C}_{\mathrm{T}} \\
& \text { Alkalinity }+\mathrm{CO}_{2} \text { acidity }=\mathrm{C}_{\mathrm{T}}
\end{aligned}
$$

Clearly, each equation incorporates an extra parameter so that the initial problem remains unchanged, that is, two independent parameters need to be measured.

Usually $\left(\mathrm{H}^{+}\right)$can be measured via operational $\mathrm{pH}$ observation (i.e. the $\mathrm{pH}$ value measured relative to National Bureau of Standards buffer solutions). The remaining parameter is obtained by considering various alkalinity and acidity capacity parameters applicable to the system. Of these capacity parameters, Alkalinity and $\mathrm{CO}_{2}$ acidity normally are considered to be easily measurable via strong acid/base titration to a prescribed end-point (about 4.5 and 8.3 respectively) with minimal error involved.

\section{Measurement of Alkalinity and $\mathrm{CO}_{2}$ acidity using Gran titrations}

Gran (1952) showed that functions can be formulated for alkalimetric and acidimetric titrations and used for determining the various capacity parameters independent of a titration end-point. Detailed formulation of these functions is set out in Appendix A.

In brief, determination of Alkalinity is effected from standard strong acid titration data effected in a pH region below the $\mathrm{H}_{2} \mathrm{CO}_{3}$ equivalence point. The appropriate Gran function, $\mathrm{F}_{1 \mathrm{X}}$, in this region being:

$$
F_{1 X}=-10^{-p H_{x}} \cdot\left(V_{s}+V_{x}\right)=C_{a} \cdot\left(V_{e}-V_{x}\right)
$$

where:

$$
\begin{aligned}
\mathrm{V}_{\mathrm{e}}= & \begin{array}{l}
\text { the unknown volume of standard strong acid to be } \\
\text { added to reach the } \mathrm{H}_{2} \mathrm{CO}_{3} \text { equivalence point }(\mathrm{m} \ell),
\end{array} \\
\mathrm{V}_{\mathrm{x}}= & \begin{array}{l}
\text { the volume of standard strong acid added to a point } \mathrm{x} \\
\text { with } \mathrm{pH} \text { equal to } \mathrm{pH}_{\mathrm{x}}(\mathrm{m} \ell),
\end{array} \\
\mathrm{C}_{\mathrm{a}}= & \text { concentration of standard strong acid }(\mathrm{mol} / \ell) \text {, and } \\
\mathrm{V}_{\mathrm{s}}= & \text { volume of sample analysed }(\mathrm{m} \ell) .
\end{aligned}
$$

Values for $\mathrm{F}_{1 \mathrm{x}}$ are obtained by inserting titration data in the region $3.5<\mathrm{pH}<4$ in the left-hand side of Eq. (10), i.e. Plotting $\mathrm{F}_{1 \mathrm{x}}$ vs. $\mathrm{V}_{\mathrm{x}}$ gives a linear relationship and its extrapolation to $\mathrm{F}_{1 \mathrm{X}}=0$ (i.e. where the line intercepts with the vertical axis) gives the value of $\mathrm{V}_{\mathrm{e}}$. The desired Alkalinity is thus determined as:

$$
\text { Total alk }_{(\text {moles } / l)}=\frac{V_{e} \cdot C_{a}}{V_{s}}
$$

Determination of $\mathrm{CO}_{2}$ acidity is effected from titration data in the region $6<\mathrm{pH}<7$. The appropriate Gran function, $\mathrm{F}_{2 \mathrm{X}}$, in this region is:

$$
F_{2 x}=10^{-(p H)_{X}} \cdot\left(V_{e}-V_{x}\right)=-K_{1}^{\prime}\left(V_{f}-V_{x}\right)
$$

where:

$\mathrm{V}_{\mathrm{f}}=$ the unknown volume of standard strong acid/base to be added to reach the $\mathrm{HCO}_{3}^{-}$equivalence point (m $\ell$ ).

Values for $\mathrm{F}_{2 \mathrm{x}}$ are obtained by inserting titration data into the left- 
hand-side term of Eq. (12), after $\mathrm{V}_{\mathrm{e}}$ has been determined via the first Gran function. Inspection of the right-hand-side term shows that a plot of $F_{2 X}$ vs. $V_{X}$ is linear and extrapolation to $F_{2 X}=0$ (i.e. where the line intercepts with the vertical axis) gives $\mathrm{V}_{\mathrm{f}}$, that is the volume of strong acid/base to reach the $\mathrm{HCO}_{3}^{-}$equivalence point. The desired $\mathrm{CO}_{2}$ acidity is determined as:

$$
\mathrm{CO}_{2} \text { acidity }_{(\text {moles } / l)}=\frac{V_{f} \cdot C_{a}}{V_{s}}
$$

It should be noted that for low alkalinity waters, the second Gran function is not useful because of $\mathrm{pH}$ instability. In order to obtain stable $\mathrm{pH}$ observations one may increase both $\mathrm{C}_{\mathrm{T}}$ (to increase buffer capacity) and ionic strength (to increase conductivity). Increase in $\mathrm{C}_{\mathrm{T}}$ can be effected by addition of a standard bicarbonate solution, termed "a spike" in this paper. The standard bicarbonate solution is designed as an equivalent bicarbonate solution in equilibrium with the air, i.e. Alkalinity $=$ Acidity, and $\mathrm{CO}_{2}$ acidity $=0$ (this is attained ONLY at $96.5 \mathrm{mg} / \ell \mathrm{NaHCO}_{3}$ that is Alkalinity = Acidity $=57.5 \mathrm{mg}$ as $\mathrm{CaCO}_{3}$ or $1.15 \mathrm{mmol} / \ell$ ). This standard solution remains unchanged with time enabling a long usage period. The modified Gran functions for the blend of sample and standard bicarbonate are as below (the full development of these functions is given in Appendix A):

$$
\begin{aligned}
& F_{1 X}=-10^{-p H_{X}} \cdot\left(V_{s}+V_{H}+V_{x}\right)=C_{a} \cdot\left(V_{e}-V_{x}\right) \\
& F_{2 x}=10^{-(p H)_{X}} \cdot\left(V_{e}-V_{x}\right)=-K_{1}^{\prime} \cdot\left(V_{f}-V_{x}\right) \\
& \text { here: } \\
& V_{H}=\text { volume of spike added to the sample }(\mathrm{m} \ell) .
\end{aligned}
$$

where:

From a measurement standpoint, $\mathrm{V}_{\mathrm{e}}$ and $\mathrm{V}_{\mathrm{f}}$ are obtained as before from strong acid titration data in the relevant $\mathrm{pH}$ regions. Note that the $\mathrm{V}_{\mathrm{e}}$ and $\mathrm{V}_{\mathrm{f}}$ data determined above refer to those for the blend of raw water sample and bicarbonate spike. The raw water Alkalinity and Acidity values are then determined using Eqs. (8) and (9) and simple stoichiometric considerations giving:

$$
\begin{aligned}
& \text { Alkalinity raw }=\left[\text { Alkalinity blend } \cdot\left(V_{H}+V_{s}\right)-V_{H} \cdot \text { spike }_{\text {alk }}\right] / V_{s}(16) \\
& \text { Acidity raw }=\left[\text { Acidity blend } \cdot\left(V_{H}+V_{s}\right)-V_{H} \cdot \text { spike }_{\text {acd }}\right] / V_{s} \\
& \text { where: } \\
& \qquad \text { spike }_{\text {alk }}=\begin{array}{l}
\text { spike }_{\text {acd }}=57.5 \mathrm{mg} / \text { as } \mathrm{CaCO}_{3}(\text { standard bicarbonate } \\
\text { solution }) .
\end{array}
\end{aligned}
$$

With the above basic considerations in mind, it is possible to evaluate critically the various methods for characterising lowalkalinity waters in the laboratory. Note that determination of $\mathrm{V}_{\mathrm{f}}$ (to calculate $\mathrm{CO}_{2}$ acidity) is effected by extrapolation of data based on $\mathrm{pH}$ measurements in the region $6<\mathrm{pH}<7$. It will be shown that this extrapolation is sensitive to small $\mathrm{pH}$ uncertainties. This arises due to the extremely large extrapolation of a plot in which the slope of the regression line is six orders of magnitude greater than the $V_{f}$ value. Nevertheless, recognising that $\mathrm{CO}_{2}$ acidity of these waters is usually very low $\left(<3 \mathrm{mg} / \ell\right.$ as $\left.\mathrm{CaCO}_{3}\right)$, even an error of $50 \%$ in this determination has a relatively minor effect on Acidity. This is important, because the chemical dosing to be applied to the water in the treatment works is based on Acidity value and not $\mathrm{CO}_{2}$ acidity.

Alternatively, the data points can be used individually and the drawback of extrapolation is circumvented. This constitutes the second indirect option of characterisation described in the introduction.

It is to be noted that characterisation via a double Gran function leads to measurement of two capacity parameters - an approach which is independent of factors affecting potentiometric observations and equilibrium constants such as temperature, pressure, and ionic strength. In contrast, the second approach utilises $\mathrm{pH}$ measurements directly (on a sample modified to allow stable $\mathrm{pH}$ readings), and depends on all factors affecting equilibrium constants.

\section{Materials and methods}

Acidity and Alkalinity measurements were carried out on two lowalkalinity waters originating from the southern coast of South Africa (Port Elizabeth and Knysna). The water samples were initially processed for humic acids removal using $\mathrm{Fe}_{2}\left(\mathrm{SO}_{4}\right)_{3}$ and $\mathrm{NaOH}$ and their $\mathrm{pH}$ was set at approximately $\mathrm{pH} 6$ prior to characterisation.

Standard bicarbonate and hydrochloric acid solutions and standardisation of these is described in detail in Appendix B.

Inorganic carbon was measured by means of a Shimadzu TOC $-5000 \mathrm{~A}$ analyser.

Instruments used: Metrohm digital titrator 715, Metrohm $\mathrm{pH}$ meter 744 with combined electrode 6.0228.000, Schott $\mathrm{pH}$ meter model CG816 with Orion reference electrode model 90-01 and glass electrode $\mathrm{Ag} / \mathrm{AgCl}$ 9101SC. Calibration of $\mathrm{pH}$ was effected with $\mathrm{pH} 4$ and $\mathrm{pH} 7$ NBS buffers.

\section{Results and discussion}

Two low-alkalinity water samples (from Knysna and Port Elizabeth) were used to assess three methods of characterisation. These were:

a Alkalinity and $\mathrm{pH}$ measurement of the raw water sample.

b Alkalinity and $\mathrm{CO}_{2}$ acidity measurements (effected via Gran functions) for a blend of the raw water, standard bicarbonate solution, and sodium chloride.

c Alkalinity measurement and $\mathrm{pH}$ measurement (in the region $6.3<\mathrm{pH}<7.0$ ) effected on the blend described in (b) above. Note that the $\mathrm{pH}$ - strong acid titration data used to effect the analysis for $\mathrm{CO}_{2}$ acidity determination in (b) above, are used also in this approach.

\section{Characterisation via Alkalinity and $\mathrm{pH}$ measurements on the raw water}

Determination of Alkalinity for the two samples was effected via the first Gran function (Eq. (14)). The results of these are listed in Table 2.

$\mathrm{pH}$ measurement of the raw samples was attempted using a "general purpose" combined electrode (Metrohm, 6.0228.000), and a specialised glass electrode plus a rapid-flow reference electrode (Orion, model Ag/AgCl 9101SC and 90-01 respectively), recommended for $\mathrm{pH}$ measurement in low-conductivity waters. Neither probe gave stable $\mathrm{pH}$ observations for the two samples analysed (Fig. 1). Consequently, this option was abandoned.

The observed drift in $\mathrm{pH}$ probably reflects the broad spectrum of $\mathrm{pH}$ data reported by various analytical laboratories for the Port Elizabeth water samples sent to them for analysis (Table 1).

\section{Alkalinity and $\mathrm{CO}_{2}$ acidity measurement via Gran functions (the double Gran function method)}

Samples of the two waters to be analysed were each blended with standard bicarbonate solution (see Appendix B) in the volumetric 


\begin{tabular}{|c|c|c|c|c|}
\hline \multicolumn{5}{|c|}{$\begin{array}{c}\text { TABLE } 1 \\
\text { pH and Alkalinity results measured by commercial analytical } \\
\text { laboratories (Port Elizabeth water) }\end{array}$} \\
\hline Laboratory & $\mathrm{pH}$ & $\begin{array}{l}\text { Alkalinity } \\
(\mathbf{m g} / \ell \text { as } \\
\left.\mathrm{CaCO}_{3}\right)\end{array}$ & $\begin{array}{l}\text { Calculated } \\
\text { Acidity* } \\
\left(\mathrm{mg}^{*} \text { as }\right. \\
\left.\mathrm{CaCO}_{3}\right)\end{array}$ & $\begin{array}{c}\text { “True" Alkalinity } \\
\text { (via Gran titration) } \\
\text { and Acidity } \\
\text { (via IC measurement) } \\
\text { (mg/l as } \mathrm{CaCO}_{3} \text { ) }\end{array}$ \\
\hline 1 & 6.0 & 2.0 & 10.9 & \multirow{5}{*}{$\begin{array}{c}\text { Alkalinity }=2.80 \\
\text { Acidity }=5.78\end{array}$} \\
\hline 2 & 5.9 & 4.0 & 13.3 & \\
\hline 3 & 6.9 & 2.0 & 3.1 & \\
\hline 4 & 5.43 & 2.8 & 105.2 & \\
\hline 5 & 6.1 & 2.8 & 4.3 & \\
\hline \multicolumn{5}{|c|}{ * calculated @ $25{ }^{\circ} \mathrm{C}, \mathrm{EC}=10 \mathrm{~ms} / \mathrm{m}$} \\
\hline
\end{tabular}

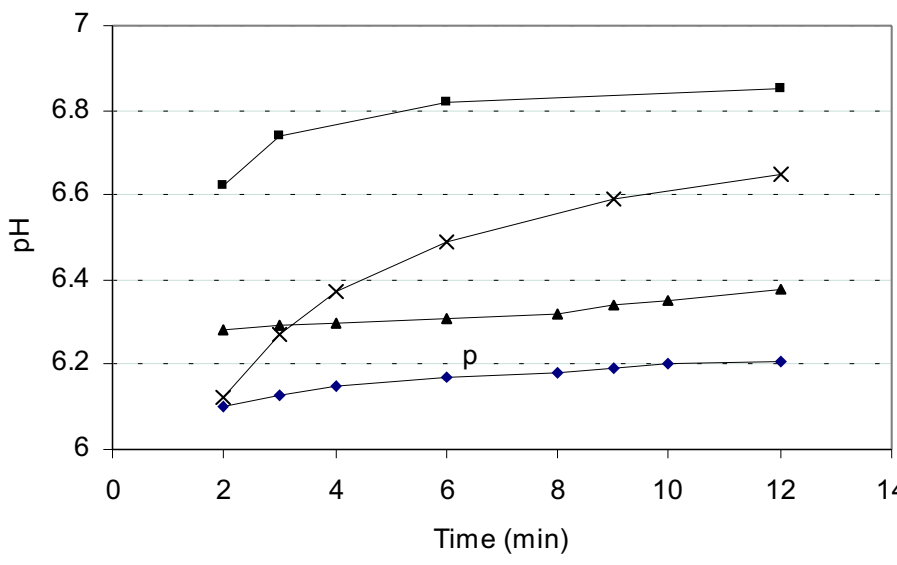

- Knysna (specialized probe) —— Port Elizabeth (specialized)

$\_$Knysna (conventional probe) $\longrightarrow$ Port Elizabeth (conventional)

Figure 1

pH measurement with time for Knysna and Port Elizabeth samples, with specialised (Orion) and conventional (Metrohm) probes

ratio 4 to 1 (Knysna) and 6.78 to 1 (Port Elizabeth). The solutions were then titrated with standard acid (for a selection of blending ratio and titration information, see Appendix B) to obtain four $\mathrm{pH}$ data points in the region $6.3<\mathrm{pH}<7.0$ (to be used with the second Gran function), and another 5 points in the region $3.5<\mathrm{pH}<4.0$ (to be used with the first Gran function).

The raw titration data (in duplicate, for each water sample) are listed in Table 3. Excellent repeatability was obtained between the duplicates (normally within $\pm 0.01 \mathrm{pH}$ units).

Alkalinity and $\mathrm{CO}_{2}$ acidity results calculated from these data via the first and second Gran functions (and the accuracy of the linear regressions) are listed in Table 4.

Figures 2 and 3 show plots of the first and the second Gran functions for a blended sample of the Knysna water. In all cases, linearity was excellent (with $\mathrm{R}^{2}>99.7 \%$ ). Comparing Acidity determined for repetitions (i.e. precision), the values determined are close in terms of concentrations, i.e. 4.33 and $5.15 \mathrm{mg} / \ell$ as $\mathrm{CaCO}_{3}$ for Knysna, and 4.31 and $4.01 \mathrm{mg} / \ell$ as $\mathrm{CaCO}_{3}$ for Port Elizabeth. In order to assess accuracy of the method, results were compared with Acidity determined from observed Alkalinity and
TABLE 2

Raw water Alkalinity measured via first Gran function (average of triplicates)

\begin{tabular}{|l|c|c|}
\hline Sample & $\begin{array}{c}\text { Alkalinity } \\
\left(\mathbf{m g} / \ell \text { as } \mathbf{C a C O}_{3}\right)\end{array}$ & $\begin{array}{c}\text { Average linear } \\
\left.\text { regression } \mathbf{( R}^{2}\right)\end{array}$ \\
\hline Knysna & $1.13 \pm 0.05$ & 0.9998 \\
Port Elizabeth & $2.80 \pm 0.04$ & 0.9999 \\
\hline
\end{tabular}

\begin{tabular}{|c|c|c|c|}
\hline \multicolumn{4}{|c|}{$\begin{array}{c}\text { TABLE } 3 \\
\text { Raw titration data (in duplicate) }\end{array}$} \\
\hline & $\begin{array}{c}\text { Standard acid } \\
\text { addition }(\mathrm{m} \ell)\end{array}$ & pH 1 & $\mathrm{pH} 2$ \\
\hline \multirow{2}{*}{ Knysna } & $\begin{array}{l}1.485 \\
2.905 \\
4.025 \\
5.485\end{array}$ & $\begin{array}{l}6.93 \\
6.71 \\
6.55 \\
6.36\end{array}$ & $\begin{array}{l}6.91 \\
6.71 \\
6.56 \\
6.37\end{array}$ \\
\hline & $\begin{array}{l}21.620 \\
23.775 \\
26.895 \\
30.190 \\
34.715\end{array}$ & $\begin{array}{l}3.98 \\
3.90 \\
3.81 \\
3.73 \\
3.66\end{array}$ & $\begin{array}{l}3.98 \\
3.90 \\
3.81 \\
3.72 \\
3.66\end{array}$ \\
\hline \multirow{2}{*}{$\begin{array}{l}\text { Port } \\
\text { Elizabeth }\end{array}$} & $\begin{array}{l}1.845 \\
3.015 \\
4.025 \\
5.140\end{array}$ & $\begin{array}{l}6.78 \\
6.57 \\
6.40 \\
6.22\end{array}$ & $\begin{array}{l}6.78 \\
6.57 \\
6.39 \\
6.21\end{array}$ \\
\hline & $\begin{array}{l}18.790 \\
21.350 \\
23.700 \\
27.260 \\
32.600\end{array}$ & $\begin{array}{l}3.96 \\
3.86 \\
3.79 \\
3.70 \\
3.61\end{array}$ & $\begin{array}{l}3.95 \\
3.85 \\
3.79 \\
3.70 \\
3.61\end{array}$ \\
\hline
\end{tabular}




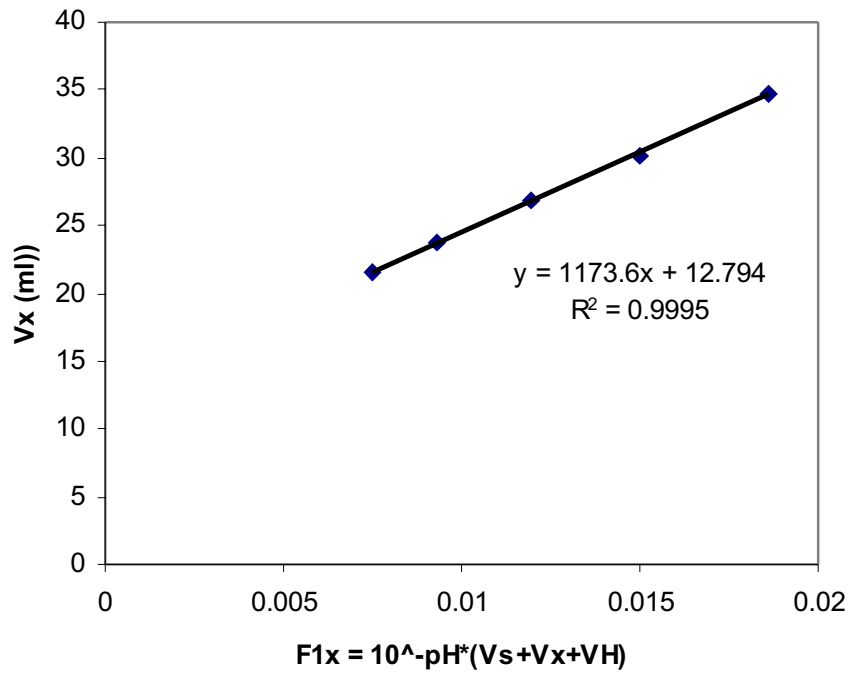

Figure 2

First Gran function regression curve for Knysna water blend, Sample 1 ( $V e=12.794 \mathrm{ml}, R^{2}=0.9995$ )

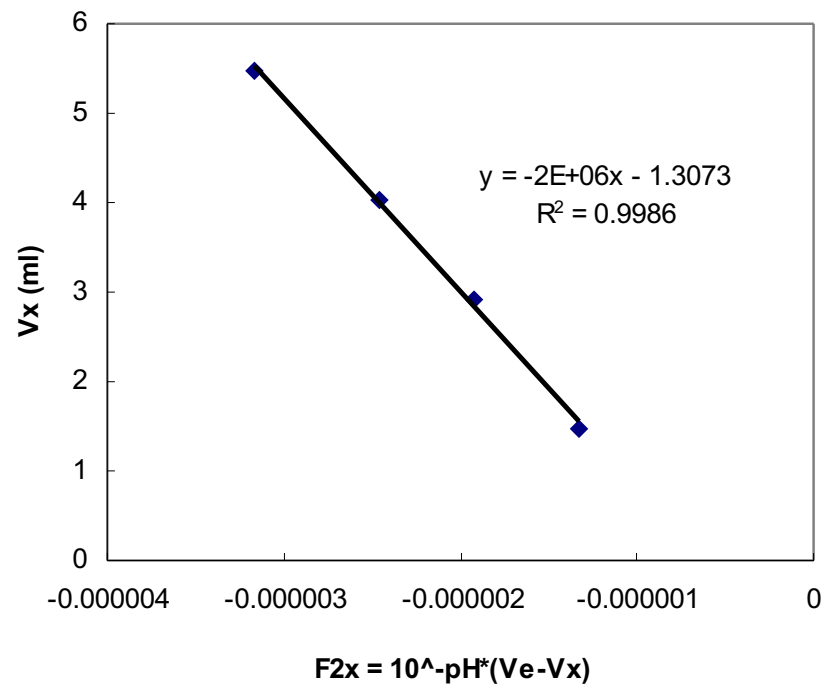

Figure 3

Second Gran function regression curve for Knysna water blend Sample $1\left(V_{f}=1.307 \mathrm{ml}, R^{2}=0.9986\right)$

\begin{tabular}{|c|c|c|c|}
\hline \multicolumn{4}{|c|}{$\begin{array}{c}\text { TABLE } 4 \\
\text { Double Gran function results }\end{array}$} \\
\hline Sample & $\begin{array}{c}\text { Alkalinity - blend } \\
\left(\mathrm{mg} / \ell \text { as } \mathrm{CaCO}_{3}\right) \\
\left(\text { in brackets }-\mathrm{R}^{2}\right)\end{array}$ & $\begin{array}{c}\mathrm{CO}_{2} \text { acidity - } \\
\text { raw water } \\
\left.(\mathrm{mg} / \ell \text { as } \mathrm{CaCO})_{3}\right) \\
\left(\text { in brackets }-\mathrm{R}^{2}\right)\end{array}$ & $\begin{array}{c}\text { Acidity - } \\
\text { raw water } \\
(\mathrm{mg} / \ell \text { as } \\
\left.\mathrm{CaCO}_{3}\right)\end{array}$ \\
\hline Knysna 1 & $12.61(0.9995)$ & $1.62(0.9986)$ & 4.33 \\
\hline Knysna 2 & 12.63 (0.9999) & $2.03(0.9967)$ & 5.15 \\
\hline Port Elizabeth 1 & $10.58(0.9998)$ & $0.75(0.9980)$ & 4.31 \\
\hline Port Elizabeth 2 & $10.26(0.9995)$ & $0.61(0.9971)$ & 4.01 \\
\hline
\end{tabular}

$\mathrm{C}_{\mathrm{T}}$ obtained from a total inorganic carbon analyser. Again, Acidity results are very close (i.e $4.87 \mathrm{mg} / \mathrm{l}$ as $\mathrm{CaCO}_{3}$ from Alkalinity and $\mathrm{C}_{\mathrm{T}}$ data vs. 4.33 and 5.15 for Knysna, and 5.78 $\mathrm{mg} / \ell$ as $\mathrm{CaCO}_{3}$ versus 4.31 and 4.01 for Port Elizabeth).

As previously noted, determination of $\mathrm{CO}_{2}$ acidity is extremely sensitive to small differences in $\mathrm{pH}$ (which result in very small differences in the slope of the regression curve) and as such may create large errors in utilising the second Gran function because of the large extrapolation involved. This phenomenon is shown for the titration results obtained from the blend effected for Knysna

TABLE 5

Sensitivity test for double Gran method - Results obtained from different three-point data combinations (Knysna 1 sample)

\begin{tabular}{|l|c|c|c|c|}
\hline $\begin{array}{l}\text { Points } \\
\text { combination }\end{array}$ & $\begin{array}{c}\mathbf{V}_{\mathbf{f}} \\
(\mathbf{m} \ell)\end{array}$ & $\begin{array}{c}\mathbf{C O}_{2} \text { acidity } \\
\text { (blend) } \\
(\mathbf{m g} / \ell \text { as } \\
\mathbf{C a C O} \text { ) }\end{array}$ & $\begin{array}{c}\mathbf{C O}_{2} \text { acidity } \\
(\mathbf{r a w} \text { water) } \\
(\mathbf{m g} / \ell \text { as } \\
\mathbf{C a C O}_{3} \text { ) }\end{array}$ & $\mathbf{R}^{2}$ \\
\hline Four points & 1.31 & 1.295 & 1.62 & 0.9986 \\
Points 1, 2,3 & 1.45 & 1.44 & 1.80 & 0.9985 \\
Points 2, 3, 4 & 1.05 & 1.04 & 1.30 & 1 \\
Points 1, 3, 4 & 1.37 & 1.36 & 1.70 & 0.9995 \\
Points 1, 2, 4 & 1.31 & 1.29 & 1.62 & 0.9987 \\
Average & & & $1.61 \pm 0.19$ & \\
\hline
\end{tabular}

water, Sample 1. For this sample, four $\mathrm{pH}$ observations were effected in the $\mathrm{pH}$ region used for $\mathrm{CO}_{2}$ acidity determination. The sensitivity of the second Gran function was then assessed as follows: accepting that the four data points did not give $100 \%$ linearity, the data were grouped into four sets of three-point data combinations on which Gran analyses were effected. Referring to these analyses in Table $5, \mathrm{CO}_{2}$ acidity varies from 1.30 to $1.80 \mathrm{mg} / \mathrm{l}$ as $\mathrm{CaCO}_{3}$ compared with $1.62 \mathrm{mg} / \ell$ as $\mathrm{CaCO}_{3}$ obtained from 4 points. Although the percentage differences appear large, Acidity values calculated from these vary only between 3.70 to $4.69 \mathrm{mg} / \ell$ respectively, and the $\mathrm{pH}$ value of the raw water calculated from these Acidity data (and Alkalinity of $1.13 \mathrm{mg} / \ell$ as $\mathrm{CaCO}_{3}$ ) gives 6.32 and 6.19 respectively.

\section{Alkalinity and $\mathrm{pH}$ observations using a bicarbonate blend (The "blend" method)}

Samples of the two waters were created as in (b) above, and titrated with standard acid to obtain $\mathrm{pH}$ titration data in the regions $6.3<\mathrm{pH}<7.0$ and $3.5<\mathrm{pH}<4.0$ (i.e. exactly the same experimental data as in (b) above were utilised here). However, the titration data are now analysed differently. In a particular titration, the Alkalinity (in the form of $\mathrm{V}$ of the blend derived from the first Gran function) is used together with the various $\mathrm{pH}$ titration data to calculate Acidity. In this calculation, in addition to the titration data one will 


\begin{tabular}{|c|c|c|c|c|c|}
\hline \multicolumn{6}{|c|}{$\begin{array}{l}\text { TABLE } 6 \\
\text { Raw water Acidity determination using the "blend" method }\end{array}$} \\
\hline Sample & $\underset{(\mathrm{m} \ell)}{\mathrm{v}_{\mathrm{x}}}$ & $\mathrm{pH}_{\mathrm{x}}$ & $\begin{array}{c}\text { Alkalinity }{ }_{\mathrm{x}}{ }^{1} \\
\text { (blend) } \\
\text { (mg/l as } \\
\mathrm{CaCO}_{3} \text { ) }\end{array}$ & $\begin{array}{c}\text { Acidity }_{\mathrm{x}}{ }^{2} \\
\text { (blend) } \\
\text { (mg/l as } \\
\mathrm{CaCO}_{3} \text { ) }\end{array}$ & $\begin{array}{c}\text { Acidity } \\
\text { raw }^{3} \\
\left(\mathrm{mg}^{\prime} / \text { as }\right. \\
\left.\mathrm{CaCO}_{3}\right)\end{array}$ \\
\hline Knysna 1 & 1.485 & 6.93 & 10.84 & 16.22 & 4.66 \\
\hline (Sample to & 2.905 & 6.71 & 9.22 & 16.81 & 4.26 \\
\hline bicarbonate & 4.025 & 6.55 & 8.00 & 17.53 & 4.31 \\
\hline ratio: 4 to 1 ) & 5.485 & 6.36 & 6.48 & 18.45 & 4.42 \\
\hline Knysna 2 & 1.485 & 6.91 & 10.85 & 16.50 & 5.02 \\
\hline (Sample to & 2.905 & 6.71 & 9.23 & 16.84 & 4.30 \\
\hline bicarbonate & 4.025 & 6.56 & 8.01 & 17.34 & 4.06 \\
\hline ratio: 4 to 1 ) & 5.485 & 6.37 & 6.49 & 18.21 & 4.09 \\
\hline PE 1 & 1.845 & 6.78 & 8.43 & 13.81 & 5.90 \\
\hline (Sample to & 3.015 & 6.57 & 7.16 & 14.60 & 5.90 \\
\hline bicarbonate & 4.025 & 6.40 & 6.10 & 15.50 & 6.21 \\
\hline ratio: 6.78 to 1 ) & 5.14 & 6.22 & 4.97 & 16.62 & 6.76 \\
\hline PE 2 & 1.845 & 6.78 & 8.12 & 13.30 & 5.29 \\
\hline (Sample to & 3.015 & 6.57 & 6.85 & 13.97 & 5.14 \\
\hline bicarbonate & 4.025 & 6.39 & 5.79 & 14.95 & 5.53 \\
\hline ratio: 6.78 to 1$)$ & 5.14 & 6.21 & 4.68 & 15.92 & 5.87 \\
\hline \multicolumn{6}{|c|}{$\begin{array}{l}{ }^{1} \text { Alkalinity }{ }_{\mathrm{x}}=\left(\mathrm{V}_{\mathrm{e}}-\mathrm{V}_{\mathrm{x}}\right) * \mathrm{C}_{\mathrm{a}} /\left(\mathrm{V}_{\mathrm{s}}+\mathrm{V}_{\mathrm{H}}+\mathrm{Vx}\right), \mathrm{C}_{\mathrm{a}} \text { in this calculation }=0.000992 \mathrm{M}, \mathrm{Ve}(\mathrm{blend})=12.74, \\
12.754,10.686 \text {, and } 10.358 \mathrm{~m} \ell \text { for the four samples respectively. } \\
{ }^{2} \text { Acidity } \text { was calculated using STASOFT, with TDS }=1000 \mathrm{mg} / \ell \text { for all samples, temperature }= \\
23^{\circ} \mathrm{C} \text { and } 25^{\circ} \mathrm{C} \text { for Knysna and Port Elizabeth respectively. } \\
{ }^{3} \text { Acidity raw }=\left[\left(\mathrm{Vs}+\mathrm{V}_{\mathrm{H}}+\mathrm{Vx}\right) * \text { Acidity }_{\mathrm{x}}-\mathrm{V}_{\mathrm{H}} * 57.5-\mathrm{Vx}^{*} 0.000992 * 50000\right] / \mathrm{Vs}\end{array}$} \\
\hline
\end{tabular}

\begin{tabular}{|c|c|c|c|}
\hline \multicolumn{4}{|c|}{$\begin{array}{l}\text { TABLE } 7 \\
\begin{array}{l}\text { Summary of Acidity results obtained from the various } \\
\text { methods }\end{array}\end{array}$} \\
\hline Sample & $\begin{array}{l}\text { Acidity via } \\
\text { "blend" method } \\
\left(\mathrm{mg} / \ell \text { as } \mathrm{CaCO}_{3}\right)\end{array}$ & $\begin{array}{l}\text { Acidity via } \\
\text { double Gran } \\
\text { function } \\
\text { method }(\mathrm{mg} / \ell \\
\left.\text { as } \mathrm{CaCO}_{3}\right)\end{array}$ & $\begin{array}{c}\text { Acidity via } \\
\text { inorganic } \\
\text { carbon } \\
\text { analyzer } \\
(\mathrm{mg} / \ell \text { as } \\
\left.\mathrm{CaCO}_{3}\right)\end{array}$ \\
\hline Knysna 1 & $4.41 \pm 0.18$ & 4.33 & 4.87 \\
\hline Knysna 2 & $4.36 \pm 0.44$ & 5.15 & 4.87 \\
\hline Port Elizabeth 1 & $6.19 \pm 0.40$ & 4.31 & 5.78 \\
\hline Port Elizabeth 2 & $5.45 \pm 0.32$ & 4.01 & 5.78 \\
\hline
\end{tabular}

also use equilibrium constants adjusted for temperature and ionic strength effects. Results of this calculation are listed in Table 6. Referring to Table 6, for each $\mathrm{pH}$ value in a particular titration one can calculate an Acidity value (and $\mathrm{CO}_{2}$ acidity value). Acidity results for each titration point together with the average and standard deviation for the duplicates of the two waters are given in Table 7. Comparing these Acidity results with those determined using the double Gran function and results obtained from the inorganic carbon analyser, the results are very similar (i.e. an accuracy of approximately $\pm 1 \mathrm{mg} / \ell$ as $\mathrm{CaCO}_{3}$ ).

\section{Conclusions}

- Conventional characterisation of low alkalinity waters, i.e. via $\mathrm{pH}$ measurement and Alkalinity measurement via titration to a prescribed end-point invariably leads to large errors due to instability of the $\mathrm{pH}$ probes and an unknown titration end-point. This problem was highlighted by the large variability in results obtained from commercial analytical laboratories for a given sample of water, and by the inability to obtain stable $\mathrm{pH}$ readings in such waters even with specialised probes (see Fig. 1).

- Full characterisation of terrestrial waters requires a reliable measurement of at least two independent parameters. Recognising that Alkalinity can be accurately measured using a Gran titration, and that: - Acidity cannot be measured directly;

- measurement of $\mathrm{C}_{\mathrm{T}}$ requires an expensive inorganic carbon analyser; and

- $\mathrm{pH}$ measurement is impractical for reasons described above;

direct and indirect measurement of $\mathrm{CO}_{2}$ acidity through a second Gran function, as well as indirect Acidity measurement were considered.

- Regarding direct $\mathrm{CO}_{2}$ acidity measurement, it was concluded that the second Gran function is not applicable because of $\mathrm{pH}$ instability. In order to obtain stable $\mathrm{pH}$ observations one may 
increase both $\mathrm{C}_{\mathrm{T}}$ (to increase buffer capacity) and ionic strength (to increase conductivity). Increase in $\mathrm{C}_{\mathrm{T}}$ was effected by addition of a standard bicarbonate solution, termed in this paper "spike".

Two indirect characterisation methods were assessed with regard to the blended sample: Measurement of Alkalinity using the first Gran function and $\mathrm{CO}_{2}$ acidity using the second Gran function (termed the "double Gran function" method); and measurement of Alkalinity (as above) and measurement of $\mathrm{pH}$ of the blend after addition of standard acid to adjust the solution into a well-buffered zone $(6.3<\mathrm{pH}<7.0)$ (termed the "blend" method). From these analyses, the characteristics of the raw waters were determined.

- The $\mathrm{CO}_{2}$ acidity and Acidity results obtained from the two methods were very similar to each other and also similar to the Acidity results calculated using Alkalinity and $\mathrm{C}_{\mathrm{T}}$ measurement obtained using an inorganic carbon analyser. Acidity values for all three methods fell between 4.33 and $5.15 \mathrm{mg} / \ell$ as $\mathrm{CaCO}_{3}$ for the Knysna sample (Alkalinity $=1.13 \mathrm{mg} / \ell$ as $\mathrm{CaCO}_{3}$ ), and between 4.01 to 6.19 for the Port Elizabeth sample (Alkalinity $=2.8 \mathrm{mg} / \ell$ as $\mathrm{CaCO}_{3}$ ).

- The Double Gran function method was found to be sensitive to small $\mathrm{pH}$ differences (although the linear regression was in all cases above $99.7 \%$ ) due to an extremely large extrapolation involved in the calculation of $\mathrm{V}_{\mathrm{f}}$. Nevertheless, sensitivity tests showed that this phenomenon, although resulting in relatively large fluctuation in the $\mathrm{CO}_{2}$ acidity result, has only a small affect on the Acidity value.

- It would appear that use of either of the two indirect methods will reduce the errors involved in characterisation of low Alkalinity waters and, consequently, improve control of water treatment plants dealing with these waters.

- It is recommended that soft waters be characterised via Alkalinity and either $\mathrm{CO}_{2}$ acidity or Acidity measurement. $\mathrm{pH}$ is then determined from equilibrium considerations. In this regard, any of various computer programs can be used. In this research, STASOFT4 (Loewenthal and Morrison, 2000) was utilised.

- A detailed procedure to facilitate the execution of the two approaches is presented in Appendix B.

\section{Acknowledgements}

The writers would like to thank Mr. Sarel Pieterse and Mr. Ian Morrison from Cape Town's City Council for their indispensable assistance in this research.

\section{References}

STANDARD METHODS (1998) Standard Methods for the Examination of Water and Wastewater $\left(20^{\text {th }}\right.$ edn.) APHA.

GRAN G (1952) Determination of the equivalence point in potentiometric titrations. Part 2. The Analyst 77 661-671.

LOEWENTHAL RE and MARAIS GvR (1976) Carbonate Chemistry of Aqueous Systems - Theory and Application. Ann Arbor Science Publishers Inc, Michigan.

LOEWENTHAL RE and MORRISON I (2000) STASOFT 4 for Windows 95, 98, and NT (A user-friendly computer program for use in municipal water treatment). Project No. K5/922/0/1, Water Research Commission, Pretoria, South Africa.

\section{Appendix A}

\section{Development of modified Gran functions for the 'spiked' sample}

\section{Development of modified first Gran function for Alkalinity of spiked sample}

Total alkalinity is measured via addition of standard acid to a volume of sample $\left(\mathrm{V}_{\mathrm{s}}\right)$ to which $\mathrm{V}_{\mathrm{H}} \mathrm{m} \ell$ of standard bicarbonate has been added (i.e. "blend"). At any point in the titration, after $\mathrm{V}_{\mathrm{x}} \mathrm{m} \ell$ of standard acid has been added, the Alkalinity of the blend can be represented as follows:

$$
\text { Alkalinity }_{x}=\left(V_{e} \cdot C_{a}-V_{x} \cdot C_{a}\right) /\left(V_{s}+V_{H}+V_{x}\right)
$$

where:

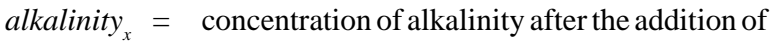

$$
\begin{aligned}
& \mathrm{V}_{\mathrm{x}} \mathrm{m} \ell \text { of standard strong acid ( } \mathrm{mol} / \ell \text { ) } \\
& \mathrm{V}_{\mathrm{e}} \quad=\quad \text { the unknown volume of standard strong acid to } \\
& \text { be added to the alkalimetric end point of the } \\
& \text { blend }(\mathrm{m} \ell) \\
& \mathrm{V}_{\mathrm{H}}=\text { volume of bicarbonate spike added }(\mathrm{m} \ell) \text {, } \\
& \mathrm{V}_{\mathrm{x}}=\text { the volume of standard strong acid added to a } \\
& \text { point } \mathrm{x} \text { with } \mathrm{pH} \text { equal to } \mathrm{pH}_{\mathrm{x}}(\mathrm{m} \ell) \\
& \mathrm{C}_{\mathrm{a}}=\text { concentration of standard strong acid }(\mathrm{mol} / \ell) \\
& \mathrm{V}_{\mathrm{s}} \quad=\text { volume of raw water sample analysed }(\mathrm{m} \ell) \text {. }
\end{aligned}
$$

Alternatively Alkalinity can be written in terms of weak acid species concentration. Equating this with Eq. (1) gives:

$$
\begin{aligned}
\text { Alkalinity }_{x} & =\left\{\left[\mathrm{HCO}_{3}^{-}\right]_{x}+2\left[\mathrm{CO}_{3}^{2-}\right]_{x}+\left[\mathrm{OH}^{-}\right]_{x}-\left[\mathrm{H}^{+}\right]_{x}\right\} \\
& =\left(V_{e} \cdot \mathrm{C}_{a}-V_{x} \cdot \mathrm{C}_{a}\right) /\left(V_{x}+V_{s}+V_{H}\right)
\end{aligned}
$$

where $[\mathrm{y}]_{\mathrm{x}}$ indicates concentration of species $\mathrm{y}$ after addition of $\mathrm{x} \mathrm{m} \ell$ of standard acid.

In the $\mathrm{pH}$ region of the titration where $\mathrm{pH}<4$, the species $\mathrm{CO}_{3}^{2}$, $\mathrm{HCO}_{3}{ }^{-}$and $\mathrm{OH}^{-}$are negligible and Eq. (2) reduces to:

$$
\text { Alkalinity }_{X}=-\left[H^{+}\right]_{X}=\left(V_{e} \cdot C_{a}-V_{X} \cdot C_{a}\right) /\left(V_{X}+V_{s}+V_{H}\right)
$$

Rearranging terms gives:

$$
-10^{-p H_{X}}\left(V_{s}+V_{H}+V_{x}\right)=C_{a} \cdot\left(V_{e}-V_{x}\right)
$$

which is defined as the first Gran function $\mathrm{F}_{1 \mathrm{x}}$. Values for $\mathrm{F}_{1 \mathrm{x}}$ are then determined from the left-hand side of Eq. 4, i.e.

$$
F_{1 x}=-10^{-p H_{x}}\left(V_{s}+V_{H}+V_{x}\right)
$$

Plotting $\mathrm{F}_{\mathrm{x}}$ vs. $\mathrm{V}_{\mathrm{x}}$ gives a linear relationship which interception with the vertical axis (i.e. where $\mathrm{F}_{\mathrm{x}}$ equals zero) gives the value of $\mathrm{V}_{\mathrm{e}}$ for the blend. The Alkalinity of the original water is thus calculated using Eq. (5):

$$
\operatorname{Alkalinity}_{(\text {moles } / l)}=\frac{V_{e} \cdot C_{a}-V_{H} \cdot\left[\text { spike }_{a l k}\right]}{V_{s}}
$$

where:

$$
\begin{aligned}
\text { spike }_{\text {alk }}= & \text { Alkalinity of standardised } \mathrm{HCO}_{3}^{-} \text {solution } \\
& (1.15 \mathrm{mmol} / \ell)
\end{aligned}
$$

\section{Development of modified second Gran function for $\mathrm{CO}_{2}$ acidity for the 'spiked' sample}

Recognising that the $\mathrm{CO}_{2}$ acidity of the standardised bicarbonate solution is zero and following the procedure set out above, the total $\mathrm{CO}_{2}$ acidity equation can be written as follows: 


$$
\begin{aligned}
\mathrm{CO}_{2} \text { acd }_{x} & =\left\{\left[\mathrm{H}_{2} \mathrm{CO}_{3}^{*}\right]_{x}-\left[\mathrm{CO}_{3}^{2-}\right]_{x}-\left[\mathrm{OH}^{-}\right]_{x}+\left[\mathrm{H}^{+}\right]_{x}\right\} \\
& =\left(V_{f} \cdot \mathrm{C}_{a}-V_{x} \cdot \mathrm{C}_{a}\right) /\left(V_{x}+V_{s}+V_{H}\right)
\end{aligned}
$$

where:

$$
\begin{aligned}
& \mathrm{CO}_{2} \operatorname{acid}_{\mathrm{x}}=\mathrm{CO}_{2} \text { acidity after addition of } \mathrm{Vx} \mathrm{m} \ell \text { standard } \\
& \text { bicarbonate solution }(\mathrm{mol} / \ell) \text { and } \\
& \mathrm{V}_{\mathrm{f}} \quad=\text { the unknown volume of standard strong base to }
\end{aligned}
$$

Acknowledging that $\mathrm{CO}_{2}$ acidity $=-\mathrm{CO}_{2}$ alkalinity, Eq. (6) can be rewritten as follows:

$$
\begin{aligned}
\mathrm{CO}_{2} \operatorname{alk}_{x} & =\left\{-\left[\mathrm{H}_{2} \mathrm{CO}_{3}^{*}\right]_{x}+\left[\mathrm{CO}_{3}^{2-}\right]_{x}+\left[\mathrm{OH}^{-}\right]_{x}-\left[\mathrm{H}^{+}\right]_{x}\right\} \\
& =-\left(V_{f} \cdot C_{a}-V_{x} \cdot C_{a}\right) /\left(V_{x}+V_{s}+V_{H}\right)
\end{aligned}
$$

In the $\mathrm{pH}$ range between 7 and 6, Eqs. (2) and (7) are respectively reduced to:

$$
\begin{aligned}
& \text { Alkalinity }_{x}=\left[\mathrm{HCO}_{3}^{-}\right]_{x}=\left(V_{e} \cdot \mathrm{C}_{a}-V_{X} \cdot \mathrm{C}_{a}\right) /\left(V_{x}+V_{s}+V_{H}\right)(8) \\
& \mathrm{CO}_{2} \text { alk }_{x}=-\left[\mathrm{H}_{2} \mathrm{CO}_{3}^{*}\right]_{x}=-\left(V_{f} \cdot \mathrm{C}_{a}-V_{x} \cdot C_{a}\right) /\left(V_{x}+V_{s}+V_{H}\right)
\end{aligned}
$$

Recognising that $\left[\mathrm{HCO}_{3}^{-}\right] /\left[\mathrm{H}_{2} \mathrm{CO}_{3}{ }^{*}\right]=\mathrm{K}_{1} /\left(\mathrm{H}^{+}\right)$, dividing Eqs. (8) and (9) yields:

$$
\frac{\text { Alkalinity }_{x}}{\mathrm{CO}_{2} \text { alk }_{x}} \cong-\frac{\left[\mathrm{HCO}_{3}^{-}\right]_{x}}{\left[\mathrm{H}_{2} \mathrm{CO}_{3}^{*}\right]_{x}}=\frac{V_{e} C_{a}-V_{x} C_{a}}{V_{f} C_{a}-V_{x} C_{a}}=-\frac{K_{1}^{\prime}}{\left(H^{+}\right)}
$$

Rearranging gives the desired equation for $\mathrm{CO}_{2}$ alkalinity:

$$
F_{2 x}=10^{-(p H)_{X}} \cdot\left(V_{e}-V_{x}\right)=-K_{1}^{\prime} \cdot\left(V_{f}-V_{x}\right)
$$

where $\mathrm{F}_{2 \mathrm{x}}$ is the second Gran function used for determining $\mathrm{CO}_{2}$ acidity as follows:

Plotting $F_{2 x}$ vs. $V_{x}$ gives a linear relationship the interception of which with the vertical axis (i.e. where $\mathrm{F}_{2 \mathrm{x}}$ equals zero) gives the value of $\mathrm{V}_{\mathrm{f}}$ (in this calculation $\mathrm{V}_{\mathrm{f}}$ will appear as a negative value due to the representation of $\mathrm{CO}_{2}$ acidity as $-\mathrm{CO}_{2}$ alkalinity).

The $\mathrm{CO}_{2}$ acidity of the original water is thus calculated using Eq. (12) (note that $\mathrm{CO}_{2}$ acidity of the standard bicarbonate solution is zero):

$$
\mathrm{CO}_{2} \text { acid }_{(\text {moles } / l)}=\frac{V_{f} \cdot C_{a}}{V_{s}}
$$

Note that another interesting feature of the second Gran function is that the slope of the curve represents the apparent equilibrium constant $\mathrm{K}_{1}^{\prime}$.

\section{Appendix B \\ Procedure for execution of the "double Gran function" and "blend" methods}

\section{Apparatus}

$1 \mathrm{pH}$ probe and reference electrode: general purpose combined electrodes cannot be used. In the work reported here an Orion glass electrode and an Orion rapid flow reference electrode were used (see Materials and methods). However, one can also use any specialised combined electrode available on the market for use with low conductivity waters.

2 Titration apparatus: a micro-burette can be used for the strong acid titration, but rather use an automatic titrator with accuracy of at least $\pm 0.01 \mathrm{~m} \ell$

3 Magnetic stirrer: any magnetic stirrer with slow and smooth stirring.

\section{Reagents}

1 Standard hydrochloric acid: dilute $0.198 \mathrm{~m} \ell$ concentrated $\mathrm{HCl}$ $(32 \%)$ in $2 \ell$ with distilled or deionised water. Add $2 \mathrm{~g} \mathrm{NaCl}$. Standardise against $20 \mathrm{~m} \ell 0.005 \mathrm{~N} \mathrm{Na}_{2} \mathrm{CO}_{3}$ solution by titrating to 4 points at $\mathrm{pH}$ values in the region $3.5<\mathrm{pH}<4$. Execute a first Gran function calculation (see The double Gran method below) to calculate the accurate standard acid concentration $\left(\mathrm{Na}_{2} \mathrm{CO}_{3}\right.$ concentration is $250 \mathrm{mg} / \ell$ as $\mathrm{CaCO}_{3}$ ).

2 Standard bicarbonate solution: dissolve $96.5 \mathrm{mg} \mathrm{NaHCO}$ in $1 \ell$ distilled or deionised water. Verify Alkalinity of solution by the first Gran function, using the standard acid. Result of titration should be very close to $57.5 \mathrm{mg} / \ell$ as $\mathrm{CaCO}_{3}$. If necessary, correct value to $57.5 \mathrm{mg} / \ell$, by either diluting with distilled water or by the addition of $\mathrm{NaHCO}_{3}$.

$3 \mathrm{NaCl}$ can be added to the blend either as powder or as a $250 \mathrm{~g} / \mathrm{\ell}$ aqueous solution.

\section{Procedure}

1 Titrate the raw sample to get 4 to 5 points between $\mathrm{pH} 4$ and 3.5 . Analyse Alkalinity using the first Gran function (see The double Gran method below).

2 Prepare the blended sample according to the following table:

\begin{tabular}{|c|c|c|c|}
\hline $\begin{array}{c}\text { If Alkalinity } \\
\text { of raw } \\
\mathrm{mg} / \ell \text { is }\end{array}$ & $\begin{array}{c}\text { Use raw } \\
\text { sample } \\
(\mathrm{m} \ell)\end{array}$ & $\begin{array}{c}\text { Standard } \\
\text { bicarbonate } \\
(\mathrm{m} \ell)\end{array}$ & $\begin{array}{c}\mathrm{NaCl} \\
(250 \mathrm{~g} / \ell) \\
(\mathrm{m} \ell)\end{array}$ \\
\hline $0.5-2$ & 45 & 5 & 0.18 \\
$2-10$ & 40 & 10 & 0.16 \\
\hline
\end{tabular}

Note: the purpose of the bicarbonate to raw sample ratio is to effect $\mathrm{pH}$ readings with a minimal $\mathrm{C}_{\mathrm{T}}$ of approximately $10 \mathrm{mg} / \ell$ as $\mathrm{CaCO}_{3}$ while not camouflaging the original acidity value. $\mathrm{NaCl}$ is added to maintain a Total dissolved solids (TDS) concentration of approximately $1 \mathrm{~g} / \ell$ throughout the titration.

3 Record the temperature of the blend solution.

4 Titrate the blend as follows: 4 points evenly distributed between $\mathrm{pH} 7.0$ to $\mathrm{pH}$ 6.3. Stir very slowly (to minimise $\mathrm{CO}_{2}$ exchange with air), and allow the $\mathrm{pH}$ to stabilise for at least $40 \mathrm{~s}$ before 
further addition of acid. After completion of the upper $\mathrm{pH}$ region, add acid to reach a $\mathrm{pH}$ below 4 and additional volume for another 4 to 5 points down to around $\mathrm{pH} 3.5$. The mixing speed at this stage can be slightly increased as the lower Gran function is not affected by $\mathrm{CO}_{2}$ loss or gain.

\section{Calculations}

\section{The double Gran method}

1 First Gran function: using the data from the lower $\mathrm{pH}$ region, set up the following table (note that if $\mathrm{NaCl}$ is added to the sample as powder $\mathrm{V}_{\mathrm{NaCl}}=0$ as developed in Appendix $\mathbf{A}$ ):

\begin{tabular}{|c|c|c|c|}
\hline Point & $\mathbf{p H}$ & $\begin{array}{c}\mathbf{F}_{1 \mathrm{x}}=10^{-} \\
{ }_{\mathrm{pH}}\left(\mathrm{V}_{\mathrm{x}}+\mathrm{V}_{\mathrm{H}}+\mathrm{V}_{\mathrm{s}}+\mathrm{V}_{\mathrm{NaCl}}\right)\end{array}$ & $\begin{array}{c}\mathbf{V}_{\mathrm{x}} \\
(\mathbf{m} \ell)\end{array}$ \\
\hline 1 & & & \\
2 & & & \\
3 & & & \\
4 & & & \\
\hline
\end{tabular}

2 Using Excel, plot $\mathrm{F}_{1 \mathrm{x}}$ ( $\mathrm{X}$ axis) versus $\mathrm{V}_{\mathrm{x}}$ ( $\mathrm{Y}$ axis), and draw a linear regression curve. The constant of the linear regression formula (i.e. where $\mathrm{F}_{1 \mathrm{x}}=0$ ) constitutes $\mathrm{V}_{\mathrm{e}}(\mathrm{m} \ell)$. $\mathrm{R}^{2}$ of the regression line should be greater than 0.999 .

$$
\begin{aligned}
& \text { Alkalinity of blend }\left(\mathrm{mg} / \ell \text { as } \mathrm{CaCO}_{3}\right) \\
& =\mathrm{V}_{\mathrm{e}} * \mathrm{C}_{\mathrm{a}} * 50000 /\left(\mathrm{V}_{\mathrm{s}}+\mathrm{V}_{\mathrm{H}}+\mathrm{V}_{\mathrm{NaCl}}\right)
\end{aligned}
$$

where:

$$
\begin{array}{ll}
\mathrm{V}_{\mathrm{e}} & =\text { linear regression constant }(\mathrm{m} \ell), \\
\mathrm{C}_{\mathrm{a}} & =\text { standard acid concentration }(\mathrm{mol} / \ell, \\
\mathrm{V}_{\mathrm{s}} & =\text { raw water volume in blend }(\mathrm{m} \ell), \\
\mathrm{V}_{\mathrm{H}} & =\text { bicarbonate volume in blend }(\mathrm{m} \ell), \\
\mathrm{V}_{\mathrm{NaCl}} & =\text { volume of } \mathrm{NaCl} 250 \mathrm{~g} / \ell \text { solution }(\mathrm{m} \ell) .
\end{array}
$$

Note: For a raw water Alkalinity (No 1 under Procedure), $\mathrm{V}_{\mathrm{H}}$ and $\mathrm{V}_{\mathrm{NaCl}}=0$.

3 Second Gran function: using the data from the upper $\mathrm{pH}$ region, and $\mathrm{V}_{\mathrm{e}}$ from $\mathbf{2}$ above, set up the following table:

\begin{tabular}{|c|c|c|c|}
\hline Point & $\mathbf{p H}$ & $\mathbf{F}_{2 \mathrm{x}}=\mathbf{1 0}^{-\mathrm{pH}}\left(\mathrm{V}_{\mathrm{e}}-\mathrm{V}_{\mathrm{x}}\right)$ & $\mathbf{V}_{\mathbf{x}}$ \\
\hline 1 & & & \\
2 & & & \\
3 & & & \\
4 & & & \\
\hline
\end{tabular}

4 Using Excel, plot $\mathrm{F}_{2 \mathrm{x}}$ ( $\mathrm{X}$ axis) vs. $\mathrm{V}_{\mathrm{x}}$ (Y axis), and draw a linear regression curve. The constant of the curve (multiplied by (-1) constitutes $V_{f}(m \ell)$. $R^{2}$ of the regression curve in this case should be greater than 0.996 .

Calculation of $\mathrm{CO}_{2}$ acidity of the raw water is based on the fact that $\mathrm{CO}_{2}$ acidity of the bicarbonate (and the $\mathrm{NaCl}$ solution) solution is zero. Hence:

$\mathrm{CO}_{2}$ acidity (raw) (mg/l as $\left.\mathrm{CaCO}_{3}\right)$

$=\left(\mathrm{V}_{\mathrm{f}} * \mathrm{C}_{\mathrm{a}} * 50000\right) / \mathrm{V}_{\mathrm{s}}$

Acidity (raw) (mg/l as $\left.\mathrm{CaCO}_{3}\right)$

$=\left[\mathrm{CO}_{2} \text { acidity }(\mathrm{raw})+\text { Alkalinity }(\mathrm{raw})\right]^{*} 2-$ Alkalinity $(\mathrm{raw})$

\section{The blend method}

1 Calculate $\mathrm{V}_{\mathrm{e}}$ of the blend using the first Gran function as in No 1 under The double Gran method.

2 For each individual titration point, carry out the following calculation (given in a tabular format):

\begin{tabular}{|c|c|c|c|c|c|}
\hline Point & $\begin{array}{c}\mathbf{v}_{\mathrm{x}} \\
(\mathrm{m} \ell)\end{array}$ & $\mathrm{pH}_{\mathrm{x}}$ & $\begin{array}{c}\text { Alkalinity } \\
(\text { blend) } \\
(\mathrm{mg} / \ell \text { as } \\
\left.\mathrm{CaCO}_{3}\right)\end{array}$ & $\begin{array}{c}\text { Acidity }_{\mathrm{x}} \\
(\mathrm{blend}) \\
(\mathbf{m g} / \ell \text { as } \\
\left.\mathrm{CaCO}_{3}\right)\end{array}$ & $\begin{array}{c}\text { Acidity } \\
\text { raw } \\
(\mathrm{mg} / \ell \text { as } \\
\left.\mathrm{CaCO}_{3}\right)\end{array}$ \\
\hline 1 & & & & & \\
2 & & & & & \\
3 & & & & & \\
\hline
\end{tabular}

- Alkalinity $_{\mathrm{x}}=\left(\mathrm{V}_{\mathrm{e}}-\mathrm{V}_{\mathrm{x}}\right) \mathrm{C} \mathrm{a}_{\mathrm{a}} /\left(\mathrm{V}_{\mathrm{s}}+\mathrm{V}_{\mathrm{H}}+\mathrm{V}_{\mathrm{NaCl}}+\mathrm{V}_{\mathrm{x}}\right)$

- Acidity is calculated using STASOFT or any other software, with TDS $=1000 \mathrm{mg} /$ and the measured temperature of the blend, using the measured $\mathrm{pH}_{\mathrm{x}}$ and the calculated Alkalinity . $^{2}$

- Acidity raw $=\left[\left(\mathrm{Vs}_{\mathrm{s}}+\mathrm{V}_{\mathrm{H}}+\mathrm{V}_{\mathrm{NaCl}}+\mathrm{Vx}\right) *\right.$ Acidity $_{\mathrm{x}}-\mathrm{V}_{\mathrm{H}} * 57.5$ $\left.-\mathrm{Vx} * \mathrm{C}_{\mathrm{a}} * 50000\right] / \mathrm{Vs}$

3 The average of the four points should be reported as the result accompanied by the corresponding standard deviation (e.g.. $4.0 \pm 0.2 \mathrm{mg} / \ell$ as $\mathrm{CaCO}_{3}$ ). 
